\title{
Impact of amphipod predation on the benthic eggs of marine fish: an analysis of Calliopius laeviusculus bioenergetic demands and predation on the eggs of a beach spawning osmeriid (Mallotus villosus)*
}

\author{
E. M. DeBlois, W. C. Leggett \\ Department of Biology, McGill University, 1205 Ave Docteur Penfield, Montreal, Québec, Canada H3A 1B1
}

\begin{abstract}
In the coastal regions of Newfoundland, Canada, the most active growth period for Calliopius laeviusculus overlaps the intertidal development of capelin eggs. At one capelin spawning beach located at Bryant's Cove (Newfoundland), we calculated that $37.6 \mathrm{mg} \mathrm{dwt}$ (dry weight) of food per $\mathrm{cm}^{2}$ of intertidal substrate were required to support C. laeviusculus population growth from June 17 to August 6,1988 . The total seasonal deposition of capelin eggs ( $236 \mathrm{mg} \mathrm{dwt} \mathrm{cm}^{-2}$ ) was more than sufficient to meet $C$. laeviusculus energetic requirements over this period. The cumulative production of all other potential intertidal prey for C. Laeviusculus in the community over the summer was estimated at $0.3 \mathrm{mg} \mathrm{dwt} \mathrm{cm}^{-2}$ and insufficient to contribute significantly to amphipod growth. We estimated that consumption of capelin eggs accounted for ca $50 \%$ of the total production of C. laeviusculus in 1988 . In any given year and if there is little interannual variation in amphipod population size, the impact of $C$. Jaeviusculus predation on capelin eggs will vary with capelin egg deposition. In 1988, we found that $C$. laeviusculus consumed approximately $16 \%$ of the total capelin egg deposition. Interannually, predation by $C$. laeviusculus could potentially account for ca 5 to $30 \%$ of the total capelin egg deposition.
\end{abstract}

\section{INTRODUCTION}

Predation on the early life stages of marine fish can be an important mechanism of density regulation in fish populations (Peterman 1977. Hilden 1988). Studies addressing predation mortality during these stages have focussed primarily on pelagic fish eggs and larvae (reviewed in Bailey \& Houde 1989) for which rapid dispersal prevails. Only a few studies have examined the importance of predation on benthic fish eggs which normally develop in dense aggregations and which should, by virtue of their aggregation, be particularly vulnerable to predation (Hassell 1978, Dahlberg 1979, Sih 1984, McGurk 1986, 1987). Further, these few

- Contribution to the program of GIROQ (Groupe interuniversitaire de recherches océanographiques du Québec) studies have concentrated on gut content analysis of potential fish predators (e.g. Dragundsund \& Nakken 1973, Johannessen 1980, Frank \& Leggett 1984) leaving invertebrate predation on benthic fish eggs largely ignored (Nikolskii 1969, Dahlberg 1979).

In view of the potential impact of predation on the survival of benthic fish eggs, the disparity in the combined knowledge of this process compared to other potential causes of early life history mortality in marine fish, and the paucity of information on invertebrate consumers of these eggs, we sought to assess the magnitude of invertebrate predation of benthic fish eggs. The predator-prey system selected for this study involved the gammaridean amphipod Calliopius laeviusculus, which, in Newfoundland, preys predominantly on the intertidal eggs of capelin Mallotus villosus.

Capelin spawning results in egg densities on the 
order of hundreds per $\mathrm{cm}^{3}$ of beach sediment in the intertidal areas of thousands of bays and inlets in Newfoundland (Taggart \& Nakashima 1987). Capelin egg incubation in these intertidal sediments typically extends from June to August (Frank \& Leggett 1984).

Calliopius laeviusculus distribution extends beyond that of capelin to cover most of the eastern seaboard of North America (see DeBlois \& Leggett 1993 and references therein). Although $C$. laeviusculus could be classified as a trophic generalist in many of these areas, there is evidence to suggest that in Newfoundland, a close trophic link exists between this amphipod species and capelin eggs. Of 20 beaches examined along the coast of Conception Bay, Newfoundland, we observed that only those beaches where capelin had spawned $(\mathrm{n}=10)$ supported measurable $\mathrm{C}$. laeviusculus populations. Further, in a previous study conducted at Bryant's Cove, Newfoundland, an extensively studied capein spawning site (e.g. DeLafontaine 1986, Taggart 1986, Mackenzie 1991), we observed that the domed-shaped trend in $C$. laeviusculus biomass closely matched the pattern of capelin egg biomass over the capelin egg development period (DeBlois \& Leggett unpubl.).

Since Calliopius laeviusculus are expected to prey heavily on capelin eggs (DeBlois \& Leggett 1991), the magnitude of capelin egg mortality will be directly influenced by the growth of the amphipod population resident in the intertidal during the period of capelin egg development. Based on this assumption, we used field estimates of C. laeviusculus population density and growth at Bryant's Cove, Newfoundland, in 1988 and known bioenergetic constraints for $C$. laeviusculus to estimate the intensity of amphipod predation on capelin eggs and the potential contribution made by this food resource to the annual production of $C$. laeviusculus.

\section{MATERIALS AND METHODS}

\section{Sampling design}

Amphipods were sampled from the benthic intertidal community of Bryant's Cove, Newfoundland. A detailed description of the study site is given in DeBlois \& Leggett (1991). Quantitative amphipod samples were collected daily from May 18 to August 8, 1988, (except when wave height was $>0.5 \mathrm{~m}$ ) coincident with the daytime high tide period. An epibenthic sled equipped with two $0.5 \mathrm{~m}$ (width) $\times 0.25 \mathrm{~m}$ (height) $350 \mu \mathrm{m}$ nets was pushed manually (speed $=35$ to $40 \mathrm{~cm} \mathrm{~s}^{-1}$ ) over two $10 \mathrm{~m}$ transects. The sled sampled ca $1 \%$ of the total amphipod population. The magnitude of the sampling bias resulting from the use of this sampler was estimated and corrected by matching estimates of density obtained with the sled with those obtained from a more efficient quadrat sampling method (DeBlois \& Leggett 1993).

The sled sampler also collected all representatives of the planktonic community of size $>350 \mu \mathrm{m}$. Calanoid copepods, oikopleura and ctenophores occurred in these samples. Representatives of the benthic community were captured in $0.07 \mathrm{~m}^{-2}$ quadrat samples and consisted almost exclusively of detritus, oligochaetes and capelin eggs. Since capelin eggs occurred at extremely high densities in the sediment $\left(62 \mathrm{egg} \mathrm{cm}^{-3}\right.$ over a $12 \mathrm{~cm}$ depth deposition layer), we used a smaller $6.4 \mathrm{~cm}$ height $\times 4 \mathrm{~cm}$ diameter plastic corer to estimate capelin egg densities. Three cores were collected at random sites within each transect at $2 \mathrm{~d}$ intervals from June to August 1988. All samples were preserved in $5 \%$ buffered formaldehyde.

\section{Laboratory method}

Amphipoùs collected in the quadrat and sied samples were counted. Details of the methods used to estimate amphipod density are given in DeBlois \& Leggett (1993)

Amphipod length frequency distributions were generated for 17 sampling dates chosen at an average interval of $4 \mathrm{~d}$ and spanning the period of May to August 1988. Subsamples of 100 to 200 amphipods were drawn from preserved samples using a Folson splitter. The body length of these amphipods (from the anterior of the head to the end of the telson), was measured from digitized images using an Optical Pattern Recognition and measuring System (OPRS). The relationship between amphipod length ( $\mathrm{mm}$ ) and dry weight (mg dwt), was determined for 55 amphipods ranging in length from 4.5 to $15 \mathrm{~mm}$. These amphipod were dried individually for $24 \mathrm{~h}$ at $60^{\circ} \mathrm{C}$ in a forced-air oven.

Amphipod length $(\mathrm{mm})$ was related to dry mass ( $\mathrm{mg}$ dwt) as follows:

$$
\begin{aligned}
& \text { mass }=0.01 \times(\text { length })^{2.66} \\
& \mathrm{r}^{2}=0.92, F_{1.55}=621, \mathrm{p}<0.0001 .
\end{aligned}
$$

The number of gravid females in each subsample was determined. Size at maturity on any given sampling date was defined as the weight of the smallest gravid female. Size-dependent fecundity was assessed by counting the number of eggs in the brood pouch of 33 gravid females ranging in weight from 2 to $22 \mathrm{mg}$ dwt. Amphipod egg dry weight was obtained by drying 5 replicate samples of 10 eggs for 24 h at $60^{\circ} \mathrm{C}$.

Capelin egg number in samples collected at $2 \mathrm{~d}$ intervals from June 17 to August 8 was estimated as follows: 
egg number $=1352 \times$ displacement volume $(\mathrm{ml})$,

$$
r^{2}=0.99, F_{1,21}=2388, p<0.0001 \text {. }
$$

Capelin eggs counted for the construction of this model were dried for $24 \mathrm{~h}$ at $60^{\circ} \mathrm{C}$ to obtain an estimate of per egg dry weight.

Other biota present in sled or quadrat samples were categorized as detritus, calanoid copepods, capelin larvae, ctenophores, oikopleura or oligochaetes and dried for $24 \mathrm{~h}$ at $60^{\circ} \mathrm{C}$ to estimate average daily biomass per animal group. Individual dry weights were also calculated for capelin larvae, copepods and oligochaetes.

\section{Data analysis}

Calliopius laeviusculus energy budget. Daag (1976) defined the allocation of food energy ingested by individual Calliopius laeviusculus to bioenergetic pathways as follows:

$$
I=P+R+M+F+L+M O
$$

where parameters indicate energy allocated to production $(P)$, reproduction $(R)$, metabolism $(M)$, feces $(F)$, the leakage of soluble compounds through the body wall $(L)$ and molting $(M o)$.

Since the rates associated with each of these pathways are size specific, we used length-frequency data, pooled at $10 \mathrm{~d}$ intervals (Fig. 1), to determine energetic losses in mg dwt for each size class on these dates

Production: Amphipod production over the capelin egg development period (June 17 to August 6) was calculated using the instantaneous growth method applied to an average biomass in each size class (see Crisp 1971, Morin 1987):

$$
P=\sum_{j=1}^{\mathrm{m}} \sum_{l=1}^{\mathrm{n}} 0.5\left(B_{l j}+B_{i j+1}\right) \times G_{i} \times \Delta t
$$

where $P=$ production; $\mathrm{n}=$ no. of size classes; $\mathrm{m}=$ no. of sampling dates; $B_{i j}=$ the biomass of size class $i$ on sampling date $j_{i} G_{i}=$ daily growth rate ( $\mathrm{mg} \mathrm{mg}^{-1}$ ) at $8^{\circ} \mathrm{C}$ in size class $i$; and $\Delta t=$ no. of days between sampling dates $j$ and $j+1$.

Biomass on any sampling date $j$, was calculated as the product of amphipod dry weight and density in any size class $i$, on date $j$. Sizespecific density was calculated from observed relative density in each size class (Fig. 1) and total amphipod density on any sampling date $j$.

Total Calliopius laeviusculus density in
Bryant's Cove on any sampling date in 1988 has previously been defined as:

$$
\begin{aligned}
D= & -2.3310+0.1723(j) \\
& -0.003819(j)^{2}+0.0000251(j)^{3}
\end{aligned}
$$

where $D=\log _{10}$ density; and $j=$ days since the first sampling date on May 18, 1988 (DeBlois \& Leggett 1993).

Amphipod growth (mg $\mathrm{mg}^{-1} \mathrm{~d}^{-1}$ ) at $8^{\circ} \mathrm{C}$ was obtained from Daag (1976) (Fig. 2). Size-specific growth rates were defined over all intervals $j$ and $j+1$ using:

$$
G_{i}=\ln \left(\mathrm{dwt}_{j+1} / \mathrm{dwt}_{j}\right)
$$

where $G_{t}=$ size-specific growth rate; and subscripts $j$ and $j+1$ identify dry weight (dwt) at time $j$ and the expected dry weight after $1 \mathrm{~d}$ of growth $(j+1)$.

Our use of growth rates noted at $8^{\circ} \mathrm{C}$ for these calculations was justified since at temperatures ranging from 5 to $14^{\circ} \mathrm{C}$ recorded from mid June to August 1988
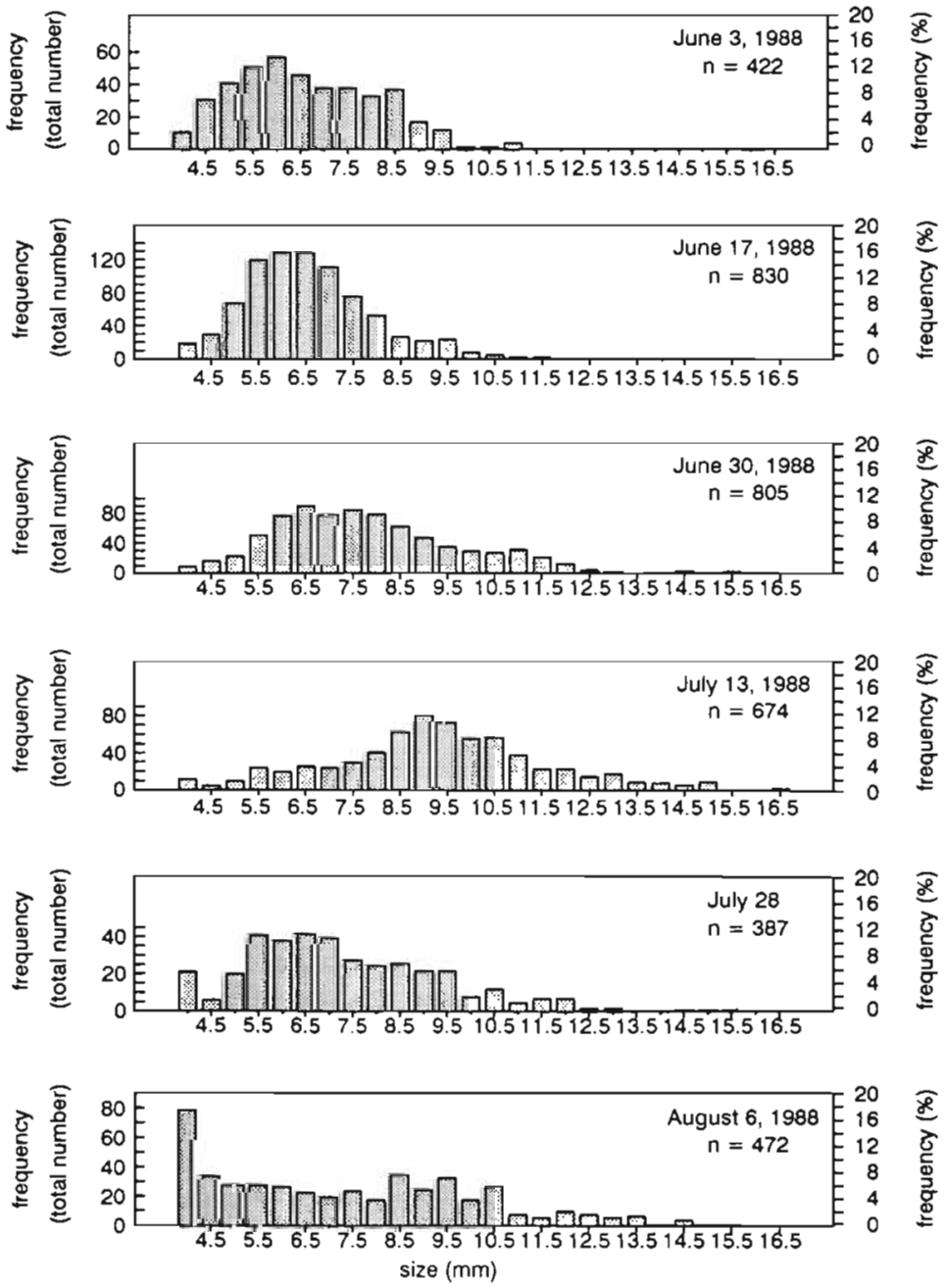

Fig. 1. Calliopius laeviusculus. Population size structure at Bryant's Cove, Newfoundland, from June to August, 1988 


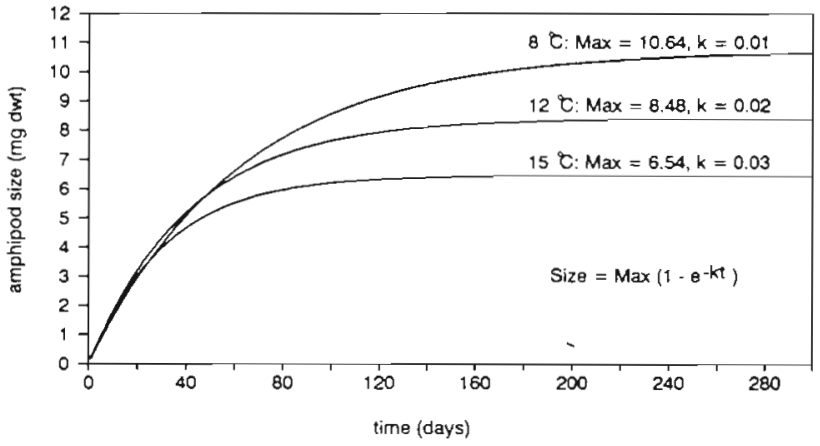

Fig. 2. Calliopius laeviusculus growth pattern at 8,12 and $15^{\circ} \mathrm{C}$ (from Daag 1976). The relationships between temperature and parameters $M a x$ and $k$ at these temperatures were defined. We found that $M a x=15.36-0.58$ (Temp.), $\mathrm{r}^{2}=0.99$, $F=404, p<0.05$, and $k=0.002$ (Temp.), $\mathrm{r}^{2}=0.99, F=203$, $p<0.05$. These parameters were then used to calculate amphipod production from fall through spring. At any given temperature, production was calculated using growth rate expressed in $\mathrm{mg} \mathrm{mg}^{-1} \mathrm{~d}^{-1}$ (see toxt, Eq. 6)

(Fig. 3) temperature-sensitive growth trajectories virtually overlap for amphipods smaller than $6 \mathrm{mg} \mathrm{dwt} \mathrm{(e.g.}$ Temp. $=8$ and $12{ }^{\circ} \mathrm{C}$, Fig. 2). The majority of Calliopius laeviusculus sampled over the summer were below this size limit. (In calculations described below, growth rate estimates were adjusted to account for temperature variation when in situ temperature fell outside the range 5 to $14{ }^{\circ} \mathrm{C}$ or amphipods were $>6 \mathrm{mg} \mathrm{dwt}$.)

Reproduction: Reproductive output was calculated as the sum of all Calliopius laeviusculus reproductive output from June 17 to August 6:

$$
R=\left(\sum_{J=1}^{\mathrm{m}} D_{\text {egg }}\right) \times \mathrm{dwt}_{\mathrm{egg}}
$$

where $R$ = total reproductive output; $m=$ total no. of sampling dates; $D_{\text {egg }}=$ density of eggs produced on any sampling date $j$ from June 17 to August 6 (DeBlois \& Leggett unpubl.); and $\mathrm{dwt}_{\text {egg }}=$ average egg weight $=0.02 \mathrm{mg} \mathrm{dwt}(\mathrm{SE}=0.006)$.

Eq. 7 yields a minimum estimate of reproductive investment since it fails to account for reproductive energy not directly stored in eggs. In the energy budget employed, the additional energetic costs to adults of egg and sperm production are incorporated into the general cost of metabolism.

Metabolism, feces, leakage and molting: The remaining bioenergetic functions for Calliopius laeviusculus expressing energy (mg dwt) allocated to metabolism, feces, leakage and molting from June 17 to August 6 were calculated as follows:

$$
\begin{aligned}
& M_{j}=0.074 \times(\text { dry mass })^{0.810} \\
& F_{j}=(100-a) \mathrm{M} / 100 \\
& L_{i}=0.3 \mathrm{M} \\
& M o_{i}=0.033 \times(\text { dry mass })^{0.521}
\end{aligned}
$$
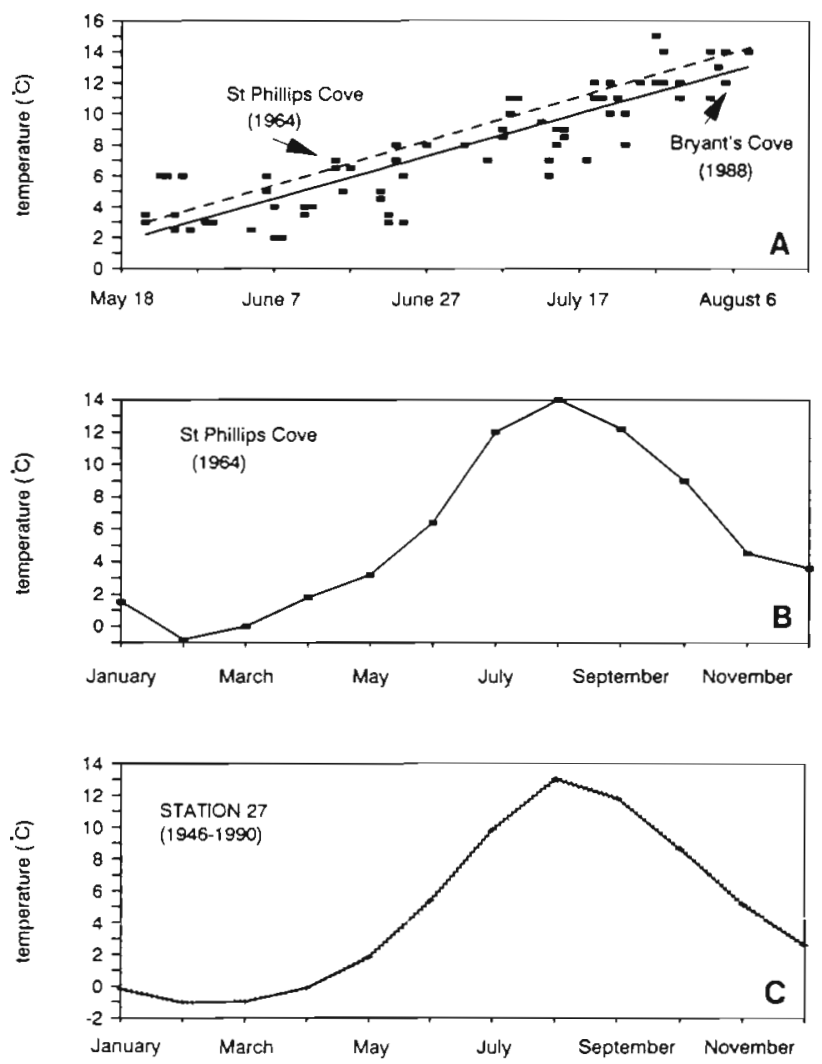

Fig. 3. (A) Summer sea temperature profiles (May to August) recorded at the low tide zone at Bryant's Cove in 1988 and St. Phillips Cove in 1964 (Steele \& Steele 1970), Newfoundland. (B) Annual sea temperature profile recorded at St. Phillips Cove in 1964 (Steele \& Steele 1970). (C) Long-term surface temperature profile, including $95 \% \mathrm{CI}$, recorded at hydrographic Stn 27. St. Johns, Newfoundland. (B. DeYoung, Memorial University, pers. comm). Temperatures recorded between May to August at Bryant's Cove in 1988 and St. Phillips Cove in 1964 did not differ significantly $\left(t_{\text {slope }}=0.22\right.$ $p>0.5, t_{\text {intercept }}=1.55, p>0.5$ ). A comparison of data from Stn 27 with 1964 data from St. Phillips Cove indicates that 1964 was not an aberrant year relative to long-term means. We used temperatures recorded at St. Phillips Cove in 1964 to es-

timate yearly variation in temperature at Bryant's Cove

where $M=$ metabolism; $F=$ feces; $a=$ assimilation efficiency; $L=$ leakage; and $M o=$ molting. As did our estimates of growth, the following functions apply to C. laeviusculus maintained at $8^{\circ} \mathrm{C}$.

Original bioenergetic functions published by Daag (1976) were expressed in $\mathrm{mg} \mathrm{C}(\mathrm{mg} \mathrm{C})^{-1}$ which provides correction for the nutritive value of the prey type tested. Eqs. 8 to 11 above are transformations of Daag's (1976) equations based on the \% carbon in both Calliopius laeviusculus ( $1 \mathrm{mg} \mathrm{dwt}=0.42 \mathrm{mg} \mathrm{C}$ ) and capelin eggs $(1 \mathrm{mg} d w t=0.45 \mathrm{mg} \mathrm{C}$ ) sampled in Newfoundland. These calculations greatly simplified our laboratory procedure and allowed an estimate $C$. laeviusculus food allocation to most of the above bioenergetic pathways, based on a diet of capelin eggs. 
Assimilation efficiency obtained from Daag (1976) was the only parameter that could not be adapted to represent a diet of capelin eggs based on egg carbon content since this estimate was reported in \% ingested matter. Calliopius laeviusculus feeding on copepods had an assimilation efficiency of $90 \%$ (Daag 1976). Owing to their higher nutritive value (see Table 2), capelin egg assimilation should be higher than that for copepods. We therefore reported our calculations assuming assimilation efficiencies ranging from 90 to $100 \%$.

To calculate total energy losses to the pathways defined in Eqs. 8 to 11, size-specific losses were multiplied by the density of animals within each size class on any given sampling date and summed over all size classes. As in calculations of production (Eq. 4), energy loss to any pathway from June 17 to August 6 was calculated using an average daily loss for populations on any 2 consecutive dates $(j, j+1)$ :

$E=\sum_{j=1}^{\mathrm{m}} \sum_{i=1}^{\mathrm{n}} 0.05\left[\left(E_{i j} \times D_{i j}\right)+\left(E_{i j+1} \times D_{i j+1}\right)\right] \times \Delta t$

where $E=$ total energy loss from June 17 to August 6; $\mathrm{n}=$ no. of size classes; $\mathrm{m}=$ no. of sampling dates; $E_{1 j}=$ individual energy loss in size class $i$ on sampling date $j$; $D_{1 j}=$ amphipod density in size class $i$ on sampling date $j$; and $\Delta t=$ no. of days between sampling dates $j$ and $j+1$.

Food intake: We expressed the total energy allocated to each bioenergetic pathway as a percentage of energy intake estimated over the capelin egg development period at Bryant's Cove in 1988 (June 17 to August 6).

Because Calliopius laeviusculus looses a significant fraction of prey body contents while feeding both as uneaten material and through seepage, amphipod predation, here defined as attacked biomass (and therefore killed) per unit time, was underestimated by calculations of population ingestion. Daag (1974) measured $30 \%$ prey loss for C. laeviusculus feeding on copepods. From published estimates of size-specific gut capacity (Daag 1976, Pederson \& Capuzzo 1984) and our observations on the total number of capelin eggs attacked in a laboratory situation where a surplus of capelin eggs was supplied (DeBlois \& Leggett 1991), we calculated that $C$. laeviusculus failed to consume $42 \%$ of capelin eggs attacked. Given these losses, we adjusted our calculation of energy intake as follows:

$$
\operatorname{Pr}=1 / 0.58
$$

where $\operatorname{Pr}=$ predation (the attacked biomass) per unit time; $I=$ required energy intake based on observed population growth; and $0.58=$ fraction of the attacked prey ingested by individual amphipods.
Estimates of energy intake were not directly available for amphipods smaller than the limits of our sampling range (length $<350 \mu \mathrm{m}$ or $0.30 \mathrm{mg} \mathrm{dwt}$ ). However, since ingestion is expected to be proportional to production (Kimmerer 1987), we calculated production for these smaller amphipods and compared this value with production noted for amphipods $>350 \mu \mathrm{m}$ sampled from June to August. Back-calculations of juvenile production can be summarized as:

$$
P=\sum_{j=\mathrm{m}}^{1}\left(D_{j} \times S_{j}\right) \times G
$$

where $P=$ production; $\mathrm{m}=$ no. of days between brood release and recruitment $\left(\mathrm{m}=8 \mathrm{~d}\right.$ at $\left.8^{\circ} \mathrm{C}\right) ; D_{j}=$ density of amphipods at time $j$ [initial $D$, is 0.45 amphipods $\mathrm{cm}^{-2}$, the total density of amphipods recruited into the sampled population from June 17 to August 6 and $D_{j-1}$ is calculated using a mortality rate $M=0.34 \mathrm{~d}^{-1}$ (from DeBlois \& Leggett unpubl.)]; $S_{j}=$ size (mg dwt) of animals at time $j$ where initial $S_{j}=0.40 \mathrm{mg} \mathrm{dwt}$, the weight of amphipods at recruitment and $S_{j-1}$ is calculated using growth rates at $8{ }^{\circ} \mathrm{C}$; and $G=$ size-specific growth at $8^{\circ} \mathrm{C}$

Food availability in the intertidal community. From production estimates for all sampled potential prey in the intertidal community, and literature-based estimates of the caloric content for these foods (Pederson \& Capuzzo 1984, K. T. Frank, Department of Fisheries and Oceans, Halifax, N.S., Canada, unpubl. data), we examined the likelihood that the amphipod population could have sustained itself over the summer months on any or all of these given food items. Since direct observation of amphipods feeding in situ were unfeasible and gut content analysis revealed only macerated material of unknown origin, we assumed that amphipods could feed in either the benthos or the plankton. For benthic biota, a prey distribution and effective amphipod foraging depth of $12 \mathrm{~cm}$ was assumed (see DeBlois \& Leggett 1991, on redistribution of capelin eggs throughout the sediment deposition column). For planktonic food, a water column height of $50 \mathrm{~cm}$ was estimated since Bryant's Cove has a mean tidal range of $100 \mathrm{~cm}$.

Production of calanoid copepods, ctenophores, oikopleura and oligochaetes was calculated using a general function which relates the production to biomass ratio to adult size at maturity in aquatic animals (Parsons 1980). We used average individual dry weight as an estimate of adult size for copepods and oligochaetes. Adult dry weights for ctenophores and oikopleura were obtained from Percy (1989) and Alldredge (1981) which related length to dry weight. Production was calculated as:

$$
P=\left(0.470 \times \overline{W t}^{-0.217}\right) \times \bar{B}
$$


where $P=$ production; $\overline{W t}=$ average dry weight $;$ and $\bar{B}=$ average biomass throughout the sampling season.

Total capelin egg deposition was calculated as the sum of increases in egg density recorded after each of 3 capelin spawning events noted over the summer (DeBlois \& Leggett unpubl.). Since capelin larvae are advected away from the nearshore upon emergence (Frank \& Leggett 1983), the total biomass of larvae available over the summer was estimated as the sum of larval biomass noted on all sampling dates. No production estimate could be found for macroalgal detritus at comparable latitudes. We therefore only report the average seasonal biomass for this potential food category. Adult Calliopius laeviusculus preferentially select animal protein over algae (Daag 1976, Pederson \& Capuzzo 1984), and it is likely that this food source was not exploited when animal prey were available.

Annual amphipod production. The calculation of amphipod production from June 17 to August 6 , when capelin eggs were abundant, is detailed above ('Calliopius laeviusculus energy budget'). Production of amphipods sampled prior to the commencement of capelin spawning was calculated similarly, but here based on growth rates expected at $4{ }^{\circ} \mathrm{C}$ and the population size structure and density of $C$. laeviusculus noted on June 3 (see Fig. 1).

It was not possible to directly estimate production for the periods prior to the beginning (May 18, 1988) and after the termination (August 8, 1988) of our sampling. Adult production over the winter months, for the interval August 8 to May 18, was estimated in a manner similar to that employed to calculate production for animals $<350 \mu \mathrm{m}$ (Eq. 14). We began calculations using average amphipod density and size on these sampling dates and either back-calculating (May 18) or forecasting (August 8 ) size and density over the remainder of the year from temperature \& size sensitive growth rates (Fig. 2) and an overwintering adult mortality rate of $M=0.01 \mathrm{~d}^{-1}$ (DeBlois \& Leggett unpubl.). Here again, we adjusted growth rate estimates to accounts for seasonal temperature variation (see Figs. 2 \& 3).

Owing to large Calliopius laeviusculus size differences, we calculated production separately for the 2 dominant amphipod cohorts present at the beginning of our sampling season (May 18) and for adults and juveniles sampled at the end of the season (August 8).

Influence of capelin egg density on predation mortality. Assuming relatively constant interannual variation in amphipod population size, the impact of amphipod predation on capelin eggs in any given year can be predicted based on capelin egg deposition.

In laboratory studies (DeBlois \& Leggett 1991), we found that amphipod feeding rates increased with capelin egg density as follows:

$$
C=11.1 \times\left(1-\mathrm{e}^{\left.-0.05 \times \vec{D}_{\text {egg }}\right)}\right.
$$

where $C$ = daily egg consumption in numbers; and $\bar{D}_{\text {egg }}=$ average capelin egg density per unit area

Using amphipod production estimates and average capelin egg densities noted in 1988, and assuming a linear relationship between daily egg consumption and amphipod production, Eq. 16 was modified to express total amphipod production over the capelin egg development period as follows:

$$
P=4.55 \times\left(1-\mathrm{e}^{\left.-0.05 \times \bar{D}_{\text {egg }}\right)}\right.
$$

Again, from analyses detailed in 'Methods - Calliopius laeviusculus energy budget', amphipod predation on eggs was related to amphipod production by:

$$
P T=8.27 P
$$

where $P r=$ amphipod predation in $\mathrm{mg} \mathrm{dwt} \mathrm{cm}^{-2}$; and $P=$ amphipod production in $\mathrm{mg} d w t \mathrm{~cm}^{-2}$.

From these functions, we calculated total seasonal egg predation by amphipods over capelin egg densities ranging from 0 to 200 eggs $\mathrm{cm}^{-3}$.

Under spawning conditions similar to those noted in 1988, average seasonal capelin egg density and total egg deposition are related by:

$$
P_{\text {egg }}=3.75 \bar{D}_{\text {egg }}
$$

where $P_{\text {egg }}=$ total capelin egg deposition in $\mathrm{mg} d w \mathrm{t}$ $\mathrm{cm}^{-2}$ ( $P_{\mathrm{egg}}$ is standardized to $\mathrm{cm}^{-2}$ assuming a capelin egg deposition depth of $12 \mathrm{~cm}$, see 'Methods - Food availability') and $\bar{D}_{\text {egg }}=$ average seasonal egg density in numbers $\mathrm{cm}^{-3}$.

The impact of amphipod predation on capelin eggs was then expressed as the ratio of total amphipod predation to capelin egg deposition.

\section{RESULTS}

\section{Calliopius laeviusculus energy requirements}

Total energy intake by the adult amphipods (>350 $\mu \mathrm{m}$ ) population of Bryant's Cove during the interval June 17 to August 6, 1988 ranged from 21.2 to $22.3 \mathrm{mg} \mathrm{dwt} \mathrm{cm}^{-2}$ (assuming assimilation efficiencies of 90 to $100 \%$ ). The distribution of energy among all pathways is given in Fig. 4.

Predation by these amphipods during the interval June 17 to August 6 ranged from 36.6 to $38.5 \mathrm{mg} \mathrm{cm}{ }^{-2}$ (after adjustment for loss of prey body content while feeding; Eq. 13).

Total capelin egg deposition in 1988 was $236 \mathrm{mg}$ dwt $\mathrm{cm}^{-2}$ (Table 1). Assuming the diet of adult Calliopius laeviusculus was dominated by capelin eggs, these amphipods consumed 15 to $16 \%$ of the total capelin egg deposition in 1988. 


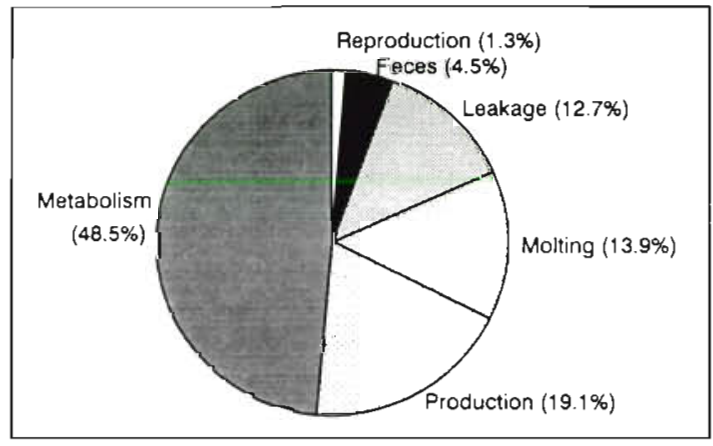

Fig. 4. Calliopius laeviusculus. Allocation of food energy to bioenergetic pathways following $I=P+R+M+F+L+M O$, where $I=$ ingestion; $P=$ production; $R=$ reproduction; $M=$ metabolism; $F=$ feces; $L=$ leakage; and $M o=$ molting. Total amphipod ingestion from June 17 to August 61988 ranged from 36.62 to $38.48 \mathrm{mg} \mathrm{dwt} \mathrm{cm}^{-2}$ assuming assimilation efficiencies ranging from 90 to $100 \%$

Production by juvenile Calliopius laeviusculus ( $<350$ $\mu \mathrm{m})$ totaled $0.4 \mathrm{mg} \mathrm{dwt} \mathrm{cm}^{-2}$ from June to August 1988 . This comparatively low production, relative to that of adults, resulted from their small size (and hence low biomass) even though their growth rates were high. Using this juvenile production estimate, we estimated that the energy intake by these animals was $1.6 \mathrm{mg}$ dwt $\mathrm{cm}^{-2}$ and that predation on capelin eggs would equate to $2.8 \mathrm{mg} \mathrm{dwt} \mathrm{cm}^{-2}$. Assuming that the diet of these smaller animals was exclusively capelin eggs, juvenile predation could account for no more than $1 \%$ of the seasonal capelin egg deposition observed in 1988.

Because the production and the potential impact of juveniles on capelin egg mortality are quite small relative to those of amphipods $>350 \mu \mathrm{m}$ in length $(0.30 \mathrm{mg}$ $d w t)$, we excluded these juveniles from any further calculations.

\section{Food availability in the intertidal}

The seasonal production of all potential food items in the intertidal community of Bryant's Cove is given in Table 1. These estimates do not include foods smaller than $350 \mu \mathrm{m}$ which were not collected with our sampling gear. Daag (1976) reports that it is unlikely that such small food items are consumed by Calliopius laeviusculus $>350 \mu \mathrm{m}$ length (although newly released $C$. laeviusculus can survive well on a diet of unicellular algae).

Our analyses suggest that the combined production of biota other than capelin eggs was insufficient to fulfill the energetic requirements of Calliopius laeviusculus during the interval June 17 to August 6, 1988 . Total production by these biota over this time was 0.3 $\mathrm{mg} \mathrm{dwt} \mathrm{cm}^{-2}$. As noted above, amphipods (>350 $\mu \mathrm{m}$ ) required an average of $37.6 \mathrm{mg} \mathrm{dwt} \mathrm{cm}^{-2}$ of food from June 17 to August 6 to maintain the growth observed.

Calliopius laeviusculus is known to select prey with higher caloric content (Pederson \& Capuzzo 1984). Of the foods available to this amphipod in the intertidal at Bryant's Cove for which caloric equivalents were available, capelin eggs had the highest energy content (Table 2). Caloric content data were unavailable for oikopleura and ctenophores, which were noted on Bryant's Cove. In terms of biomass, these animals were the 2 least important constituent of the intertidal community (Table 1).

Table 2 also provides the caloric content for adult capelin, which were not sampled with either the sled or quadrat sampler. Adult capelin die after spawning and then typically remain and decompose in large masses in the subtidal area. In the intertidal zone, we noted that Calliopius laeviusculus avoided large suspensions of dead capelin eggs which occurred following storm events. We speculated that this behavior was

Table 1. Individual dry weight, average biomass and total production (May 18 to August 6, 1988) of biotic components of the intertidal community at Bryant's Cove, Newfoundland. Biomass and production are standardized to $\mathrm{cm}^{-2}$ using depths of 50 and $12 \mathrm{~cm}$ for planktonic (p) and benthic (b) biota respectively (see 'Methods - Food availability'). NA: not available

\begin{tabular}{|c|c|c|c|}
\hline Category & $\begin{array}{l}\text { Dry wt ind. }{ }^{-1} \\
\text { (mg) }\end{array}$ & $\begin{array}{l}\text { Average seasonal biomass } \\
\qquad\left(\mathrm{mg} \mathrm{cm}^{-2}\right)\end{array}$ & $\begin{array}{l}\text { Total seasonal production } \\
\left(\mathrm{mg} \mathrm{cm}^{-2} \text { interval } \mathrm{l}^{-1}\right)\end{array}$ \\
\hline Macroalgal detritus (b) & NA & 0.12492 & $0.12492^{\mathrm{a}}$ \\
\hline Capelin eggs (b) & 0.06450 & 48 & $236^{\mathrm{b}}$ \\
\hline Capelin larvae $(p)$ & 0.05168 & 0.00595 & $0.08330^{c}$ \\
\hline Calanoid copepods (p) & 0.09150 & 0.00621 & $0.00490^{\mathrm{d}}$ \\
\hline Ctenophores \& jellyfish $(p)$ & 80.0 & 0.00380 & $0.00069^{d}$ \\
\hline Oikopleura (p) & 0.033 & 0.00390 & $0.00384^{\mathrm{d}}$ \\
\hline Oligochaetes (b) & 0.00009 & 0.01292 & $0.04590^{\mathrm{d}}$ \\
\hline \multicolumn{4}{|c|}{$\begin{array}{l}\text { a Equivalent to average seasonal biomass } \\
\text { b Sum of capelin egg biomass after } 3 \text { noted spawning events } \\
\text { c Sum of capelin larvae biomass over all sampling dates } \\
\text { d } p=0.470\end{array}$} \\
\hline
\end{tabular}


above average seasonal egg densities of 40 eggs $\mathrm{cm}^{-3}$ This relationship and the functional response of amphipods to capelin egg density as determined in laboratory studies (Eq. 16) are shown in Fig. 6. The impact of amphipod predation on eggs, expressed as the ratio between amphipod predation (Eq. 18) and total capelin egg deposition (Eq. 19) varied inversely with capelin egg density (Fig. 7). Based on reported average densities in situ for 1978, 1979 (Frank \& Leggett 1984) and 1988 (this study), it is estimated that predation by C. Iaeviusculus would account for 15 to $30 \%$ of the total capelin egg deposition.

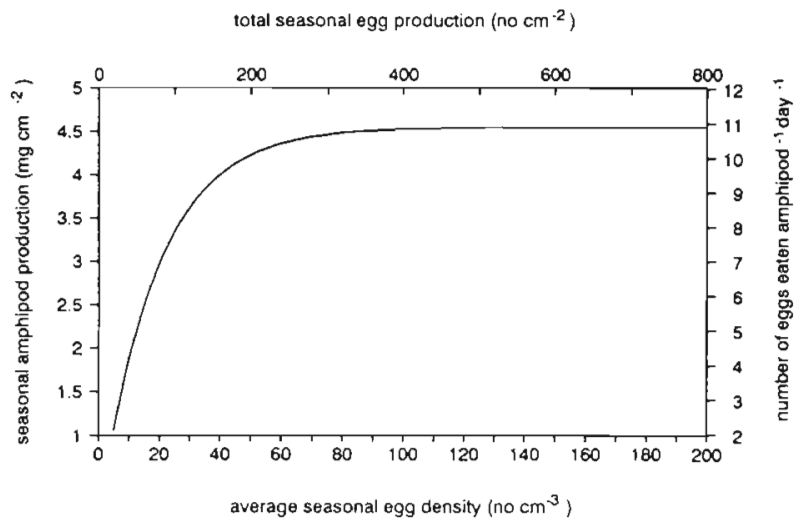

Fig. 6. Calliopius laeviusculus. Daily ingestion (DeBlois \& Leggett 1991) and resulting seasonal population production as a function of average seasonal capelin egg density. The bottom axis represents average seasonal egg density while the top axis shows corresponding egg production standardized to $\mathrm{mg} \mathrm{dwt} \mathrm{cm}^{-2}$ assuming a $12 \mathrm{~cm}$ deep egg deposition layer

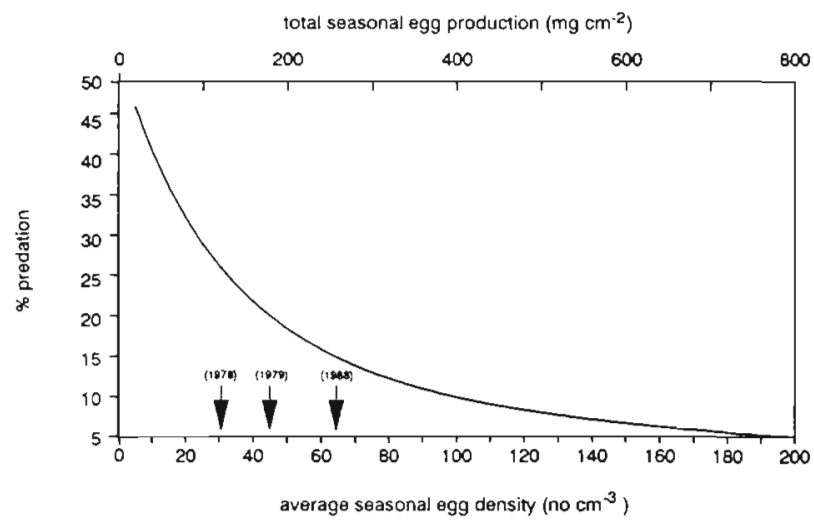

Fig. 7. Calliopius laeviusculus. Impact of amphipod predation on capelin eggs assuming varying conditions of capelin spawning effort. The bottom axis represents averages seasonal egg density while the top axis shows corresponding egg production standardized to $\mathrm{mg} \mathrm{dwt} \mathrm{cm}^{-2}$ assuming a $12 \mathrm{~cm}$ deep egg deposition layer. Average densities of 30.3 and 45.4 eggs $\mathrm{cm}^{-3}$ were noted in 1978 and 1979 by Frank \& Leggett (1984). An average density of 62 eggs $\mathrm{cm}^{-3}$ was noted in this study in 1988

\section{DISCUSSION}

During the interval June 17 to August 6, 1988, capelin egg deposition at Bryant's Cove beach totaled $236 \mathrm{mg} \mathrm{cm}^{-2} \mathrm{dwt}$. The level of predation required to support the observed Calliopius laeviusculus production over the same period was $37.6 \mathrm{mg} \mathrm{cm}^{-2} \mathrm{dwt}$. Hence, during the period of capelin egg availability, the total energy needs of $C$. laeviusculus could easily be met by predation on capelin eggs.

The energy content of all other potential amphipod prey in the intertidal was on average $2 \times$ lower than that of capelin eggs, and given their seasonal produc-

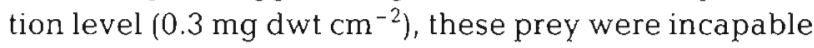
of sustaining the observed amphipod population during the interval June 17 to August 6. Moreover, it is likely that capelin eggs were preferentially selected over other biota owing to this higher energy content and their overwhelming abundance (see Krebs 1978, Peterson \& Capuzzo 1984 on prey choice for this and other predators).

Total Calliopius laeviusculus production was $4.3 \mathrm{mg}$ dwt $\mathrm{cm}^{-2}$ from June 17 to August 6 and $5.0 \mathrm{mg} \mathrm{dwt}$ $\mathrm{cm}^{-2}$ over the remainder of the year. From these estimates, a significant fraction (ca $50 \%$ ) of C. laeviusculus production occurred in the presence of capelin eggs.

Production estimates obtained here for Calliopius laeviusculus are corroborated by those obtained for other amphipod species. Given an annual production of $9.3 \mathrm{mg} \mathrm{dwt} \mathrm{cm}^{-2}$ and an average biomass of $3 \mathrm{mg}$ dwt $\mathrm{cm}^{-2}$, the $P / B$ ratio for this $C$. laeviusculus population in 1988 was 3.1. Similar $P / B$ ratios have been reported for a number of multivoltine amphipod species (Iversson \& Jenssen 1977, Mortensen 1982, Waters 1984, Kevrekidi \& Lasaridou-Dimitriadou 1988 working with the genus Gammarus; Klein et al. 1975 , Carrasco \& Arcos 1984 working with Ampelisca; Venables 1981, Wildish 1984, Johnson 1988 working with Pontoporeia).

Prior to the onset of capelin spawning on June 17 . amphipod production totaled $1.0 \mathrm{mg} \mathrm{dwt} \mathrm{cm}^{-2}$ or $23 \%$ of cumulative production observed over the summer months. This low production resulted from small amphipod sizes (i.e. low biomass, even though densities were high) and slow growth rate at the low water temperatures which prevail during these months. It is likely that these amphipods met their maintenance requirements by feeding on algae and algal detritus. Daag (1976) reported that Calliopius laeviusculus developed a greenish body color when feeding on algae. This color disappeared within $24 \mathrm{~h}$ and was replaced by a red-orange color when amphipods began to feed on zooplankton. At Bryant's Cove, an abrupt change in the color of $C$. laeviusculus gut content (from brown- 
green material, suggesting an algal diet, to unpigmented material, suggesting predation on capelin eggs) occurred at the onset of capelin spawning

By the end of August, most capelin eggs had hatched. At that time, Calliopius laeviusculus energy demands exceeded the available intertidal food supplies. Although little C. laeviusculus migration occurs from May to early August (DeBlois \& Leggett unpubl.), Steele \& Steele (1973) who studied C. laeviusculus at a nearby capelin spawning beach in St. Phillips Cove, Newfoundland, noted that in late August, C. laeviusculus swarmed to the surface and were found in the plankton, or on protected shores, where they did not normally occur. Such a dispersal mechanism would enable $C$. laeviusculus to search for alternative food sources when food levels on capelin spawning beaches became limiting. This type of migratory behavior in response to low food concentration is common in a variety of insects (see Tauber et. al. 1986 and references therein).

Other behavioral patterns could improve Calliopius laeviusculus survival once capelin eggs have hatched. In August, C. laeviusculus energy demands might have been partially met by the resorption of their own eggs. Female amphipods are known to consume their brood when food conditions are poor (Sheader 1983). Fenwick (1985) suggested that egg resorption could compensate for reproductive over-commitment often noted in amphipods and might enhance the probability of female survival over the winter months. The proportion of gravid females in the C. laeviusculus population at Bryant's Cove was highest in August (DeBlois \& Leggett unpubl.). Given low food conditions, brood cannibalism at this time might have been common. Moreover, female C. laeviusculus are known to enter a resting phase in August and to remain in reproductive stasis until the following spring (Steele \& Steele 1973). This sexual quiescence would also reduce the overwintering energy demands on adults.

The seasonal co-occurrence of high Calliopius laeviusculus and capelin egg abundances could result in significant losses to the capelin egg population. At average seasonal capelin egg densities of 5 to 200 eggs $\mathrm{cm}^{-3}$, predation mortality was estimated to vary from a maximum of $30 \%$ to a minimum of $5 \%$ of the total capelin egg deposition. Mortality due to predation decreased exponentially as average seasonal density increased. Data for 1978 and 1979 (Frank \& Leggett 1984) and 1988 (this study) suggest that amphipods consumed from 15 to $30 \%$ of the total egg deposition in these years

Capelin egg mortality will also be influenced by the size of the amphipod population at the onset of capelin spawning. At present, we have no information on interannual variation in Calliopius laeviusculus popu- lation size. Van de Veer \& Bergman (1987), studying Crangon crangon (Crustacea: decapoda) predation on 0-group plaice in intertidal nursery areas of the Wadden Sea, found that overwintering mortality in C. crangon was relatively stable and that only extremely cold winters resulted in unusually low numbers in spring.

Assuming relatively constant amphipod population size in spring, capelin egg mortality resulting from attacks by Calliopius laeviusculus may be higher than our predation estimates of 15 to $30 \%$ indicate. As noted previously, Daag (1974) showed that C. laeviusculus looses up to $30 \%$ of the body content of the prey eaten while feeding on copepods. For C. laeviusculus at Bryant's Cove feeding on capelin eggs, we estimated this Ioss at $42 \%$. Both Daag's (1974) and our study (DeBlois \& Leggett 1991) were conducted with starved amphipods. Under more natural conditions, this predator may be even less efficient in terms of the amount of prey material eaten relative to the number of prey captured (Daag 1974). In field situations, and particularly when food densities are high, intra- and interspecific contact coupled with physical disturbances could lead to the actual ingestion of an even smaller proportion of the captured prey. Lillelund \& Lasker (1971) have shown that the number of anchovy larvae killed by predaceous copepods of the genus Labidocera is often much higher than the number ingested, especially at high food concentrations.

While the estimates of predation levels by Calliopius laeviusculus on capelin eggs developed here may be conservative, they do compare favorably with several estimates of the intensity of fish predation on benthic eggs. For example, haddock Melanogrammus aeglefinus are estimated to consume up to $40 \%$ of the total annual egg deposition of Norwegian spring spawning herring Clupea harengus (Dragundsund \& Nakken 1973). In a similar study, Johannessen (1980) found that cod Gadus morhua and haddock Melanogrammus aeglefinnus ate $50 \%$ of the herring egg deposition.

Frank \& Leggett (1984) studied the intensity of predation on capelin eggs by winter flounder Pseudopleuronectes americanus at Bryant's Cove. They concluded that while predation accounted for only $3 \%$ of the capelin egg mortality, the eggs consumed by flounder contributed up to $23 \%$ of the energy required to support the observed annual growth in flounder. These findings, together with those developed here highlight the importance of capelin eggs to the energy flow and community dynamics of intertidal areas of Newfoundland.

To date, only one other study has quantified the intensity of invertebrate predation on the benthic eggs of marine fish. In this case pacific herring Clupea pallasi suffered $10 \%$ egg losses as a consequence of preda- 
tion by the amphipod Anisogammarus pugetensis (Palsson 1984). The results of this study and that of Palsson's (1984) indicate that predation by amphipods, and possibly other invertebrate species, on benthic fish eggs is at least as important as fish predation and could significantly influence survival in the egg stage. Invertebrate predation on eggs should therefore be considered when evaluating the potential regulators of reproductive success in demersal spawning fish.

\section{LITERATURE CITED}

Alldredge, A. (1981). The impact of appendicularian grazing on natural food concentrations in situ. Limnol. Oceanogr. 26: $247-257$

Bailey, K. M., Houde, E. D. (1989). Predation on eggs and larvae of marine fishes and the recruitment problem. Adv. mar. Biol. 25: 1-83

Carrasco, F. D., Arcos, D. F. (1984). Life history and production of a cold-temperate population of the sublittoral Ampelisca araucana. Mar. Ecol. Prog. Ser. 14: 245-252

Crisp, D. J. (1971). Energy flow measurements. In: Holme, N. A., McIntyre, A. D. (eds.) Methods for the study of the marine benthos. IBP handbook No. 16. Blackwell Scientific Publ., Oxford

Daag, M. J. (1974). Loss of prey body content during feeding by an aquatic predator. Ecology 4: 903-906

Daag. M. J. (1976). Complete carbon and nitrogen budgets for the carnivorous amphipod Calliopius laeviusculus (Kroyer). Int. Revue ges. Hydrobiol 61: 297-357

Dahlberg, M. D. (1979). A review of survival rates of fish eggs and larvae in relation to impact assessment. Mar. Fish. Rev. 41: 1-12

DeBlois, E. M., Leggett, W. C. (1991). Functional response and potential impact of invertebrate predators on benthic fish eggs: analysis of the Calliopius laeviusculus-capelin (Mallotus villosus) predator-prey system. Mar. Ecol. Prog. Ser. 69: 205-216

DeBlois, E. M., Leggett, W. C. (1993). Importance of biotic and abiotic regulators of abundance of the intertidal amphipod Calliopius laeviusculus (Amphipoda: Gammaridae) and assessment of the accuracy and precision of sampling methods for detecting abundance changes. Mar. Biol. 115: 75-83

DeLafontaine, Y. (1986). Experimental evaluation of the impact of macrozooplankton predation on mortality in larval capelin (Mallotus villosus Muller). Ph.D. thesis, McGill University, Montreal

Dragundsund, O. Nakken, O. (1973). Relationship of parent stock size and year-class strength in Norwegian spring herring. Rapp. P.-v. Reun. Cons. int. Exp. Mer 164: 15-29

Fenwick, G. D. (1985). Life-histories of four co-occurring amphipods from a shallow, sand bottom at Kaikoura, New Zealand. N. Z. J. Zool. 12: 71-105

Frank, K. T., Leggett, W. C. (1983). Survival of an opportunistic life-stage transition in capelin (Mallotus villosus). Can. J. Fish. Aquat. Sci. 40: 1442-1448

Frank, K. T., Leggett, W. C. (1984). Selective exploitation of capelin (Mallotus villosus) eggs by winter flounder (Pseudopleuronectes americanus): capelin egg mortality rates, and contribution of egg energy to the annual growth of flounder. Can. J. Fish. Aquat. Sci. 41: 1294-1302
Hassell, M. P. (1978). The dynamics of arthropod predatorprey systems. Princeton Univ. Press, Princeton

Hilden, M. (1988). Significance of the functional response of predators to changes in prey abundance in multispecies virtual population analysis. Can. J. Fish. Aquat. Sci. 45: $89-96$

Iverssen, T. M., Jenssen, J. (1977). Life cycle, drift and production of Gammarus pulex L. (Amphipoda) in a Danish spring. Freshwat. Biol. 7: 287-296

Johannessen, A. (1980). Predation on herring (Clupea harengus) eggs and young larvae. Int. Counc. Explor. Sea. Comm. Meet. H: 33. 1-12

Johnson, M. G. (1988). Production by the amphipod Pontoporeia hoyi in South Bay, Lake Huron. Can. J. Fish. Aquat. Sci. 45: 617-624

Kevrekidis, T., Lasaridou-Dimitriadou, M. (1988). Relative growth and secondary production of the amphipod Gammarus aequicauda (Martynov, 1931) in the Evros Delta (N. Aegean sea). Cah. Biol. Mar. 29: 483-495

Kimmerer, W. J. (1987). The theory of secondary production calculations for continuously reproducing populations. Limnol. Oceanog. 22: 1-13

Klein, G., Rachor, E., Gerlach, S. A. (1975). Dynamics and productivity of two populations of the benthic tube dwelling amphipod Ampelisca brevicornis (Costa) in Helgoland Bight. Ophelia 14: 139-159

Krebs, J. R. (1978). Optimal foraging: decision rules for predators. In: Krebs, J. R., Davis, N. B. (eds.) Behaviora! ecology: an evolutionary approach. Blackwell Scientific Publ., Oxford

Lillelund, K., Lasker, R. (1971). Laboratory studies of predation by marine copepods on fish larvae. Fish. Bull. U.S. 69 : $655-667$

Mackenzie, B. R. (1991). The influence of small-scale turbulence and upwelling on the ecology of larval fishes. Ph.D. thesis, McGill University, Montreal

McGurk, M. D. (1986). Natural mortality of marine pelagic fish eggs and larvae: role of spacial patchiness. Mar. Ecol. Prog. Ser. 34: 227-242

McGurk, M. D. (1987). Natural mortality and spatial patchiness: reply to Gulland. Mar. Ecol. Prog. Ser. 39: 201-206

Morin, A. (1987). Estimation and prediction of black fly abundance and productivity. Ph.D. thesis, McGill University, Montreal

Mortensen, E. (1982). Production of Gammarus pulex L. (Amphipoda) in a small Danish stream. Hydrobiologica 87 : $77-82$

Nikolskii, G. V. (1969). Theory of fish population dynamics Oliver and Boyd, Edinburgh

Palsson, W. A. (1984). Egg mortality upon natural and artificial substrata within Washington State spawning grounds of Pacific herring (Clupea harengus pallassi). M.Sc. thesis, University of Washington, Seattle

Parsons, T. R. (1980). Zooplankton production. In: Bames, R. S. K., Mann, K. H. (eds.) Fundamentals of aquatic ecosystems. Blackwell Scientific Publ., Oxford

Pederson, J. B., Capuzzo, J. M. (1984). Energy budget of an omnivorous rocky shore amphipod Calliopius laeviusculus (Kroyer). J. exp. mar. Biol. Ecol. 75: 277-291

Percy, J. A. (1989). Abundance, biomass and size frequency distribution of an arctic ctenophore, Mertensia ovom (Fabricus) from Frobisher Bay, Canada. Sarsia 74: 95-105

Peterman, R. M. (1977). A simple mechanism that causes collapsing stability regions in exploited salmonid populations. J. Fish. Res. Bd Can. 34: 1130-1142

Sheader, M. (1983). The reproductive biology and ecology of 
Gammarus duebeni (Crustacea: Amphipoda) in southern England. J. mar. biol. Ass. U.K. 63: 517-540

Sih, A. (1984). Optimal behavior and density-dependent predation. Am. Nat. 123: 314-326

Steele, D. H., Steele, V. J (1970). The biology of Gammarus (Crustacea: Amphipoda) in the northwest Atlantic. III. Gammarus obtusatus Dahl. Can. J. Zool. 48 989-995

Steele, D. H., Steele, V. J. (1973). Some aspects of the biology of Calliopius laeviusculus (Kroyer) (Crustacea, Amphipoda) in the northwestern Atlantic. Can. J. Zool. 51: $723-728$

Taggart, C. T. (1986). Mortality of larval capelin (Mallotus villosus): environmental and density correlates during postemergent dispersal. Ph.D. thesis, McGill University, Montreal

Taggart, C. T., Nakashima, B. S. (1987). The density of capelin (Mallotus villosus) eggs on spawning beaches in

This article was presented by C. H. Peterson, Morehead City, N. Carolina, USA
Conception Bay, Newfoundland. Can. Tech. Rep. Fish. Aquat. Sci. no. 1580

Tauber, M. J., Tauber, C. A., Masaki, S. (1986). Seasonal adaptations in insects. Oxford Univ. Press, New York

van der Veer, H. W., Bergman, M. J N. (1987). Predation by crustaceans on newly settled 0-group plaice Pleuronectes platessa population in the western Wadden Sea. Mar. Ecol. Prog. Ser. 35: 203-215

Venebles, B. J. (1981). Aspects of the population biology of Venezuelan beach amphipod Talorchestia margaritae (Talitridae) including estimates of biomass and daily production and respiration rates. Crustaceana 41:271-285

Waters, T. F. (1984). Annual production by Gammarus pseudolimnaeus among substrate types in Valley Creek, Minnesota. Am. Midl. Nat. 112: 95-102

Wildish, D. J. (1984). Secondary production of four sublittoral, soft-sediment amphipod populations in the Bay of Fundy. Can. J. Fish. Aquat. Sci. 62: 1027-1033

Manuscript first received: July 27, 1992

Revised version accepted: December 8, 1992 